\title{
A countervailing atonement: The meaning of equivalence in the American moral governmental theory of the atonement
}

\author{
Obbie Tyler Todd ${ }^{*}$ \\ New Orleans Baptist Theological Seminary, New Orleans, LA 70126 \\ ${ }^{*}$ Corresponding author. E-mail: obbiett@gmail.com
}

\begin{abstract}
In the American moral governmental theory of the atonement, the idea of equivalence is best understood in terms of a countervailing, or the achieving of a moral equilibrium. According to Jonathan Edwards' disciples, Christ's atonement was not quantifiably equivalent to the penalty of the law, but morally and meaningfully equivalent. In other words, Christ's physical and psychological sufferings were not equal in amount or degree to a sinner's damnation. Rather, Christ's substitution for divine punishment exhibited sufficient displeasure against sin to effectively communicate his character and to offset the evil effects of sin. At stake was not the moral quantity of his crucifixion, but the moral quality. In this moral governmental scheme, Christ's was not a commutative atonement, but a countervailing atonement.
\end{abstract}

Keywords: atonement; countervail; Edwardsean; equivalence; moral government; suffering

Although the 'seeds' of the American moral governmental theory of the atonement were sown by Jonathan Edwards, it was his disciples who gave life and form to the doctrine. ${ }^{1}$ In fact, several scholars have agreed that Jonathan Edwards, Jr. was its primary architect, divesting himself from his father's penal substitutionary framework. ${ }^{2}$ As a result, almost

\footnotetext{
${ }^{1}$ According to Oliver Crisp, 'The evidence suggests that the seeds of the New England governmental view of the atonement were sown by Edwards himself. But he did not have the opportunity, or perhaps the inclination, to develop this in his own work. So the views expressed by Bellamy, Samuel Hopkins, and Jonathan Edwards, Jr., to name the three most important exponents of the doctrine among the theologians of the New Divinity, were, one might think, a doctrine innovation in one respect. But they were building on some ideas latent in the work of Edwards Senior, and they did, it appears, have his sanction for doing so.' Oliver D. Crisp, 'The Moral Government of God: Jonathan Edwards and Joseph Bellamy on the Atonement', in Oliver D. Crisp and Douglas A. Sweeney (eds), After Jonathan Edwards: The Courses of the New England Theology (Oxford: OUP, 2012), pp. 78-9.

${ }^{2}$ Dorus Paul Rudisill, The Doctrine of the Atonement in Jonathan Edwards and His Successors (New York: Poseidon Books, 1971), p. 85; Robert L. Ferm, Jonathan Edwards the Younger, 1745-1801: A Colonial Pastor (Grand Rapids, MI: William B. Eerdmans, 1976), p. 115; Daniel W. Cooley and Douglas A. Sweeney, 'The Edwardseans and the Atonement', in Mark Jones and Michael A. G. Haykin (eds), A New Divinity: Transatlantic Reformed Evangelical Debates during the Long Eighteenth Century (Gottingen: Vandenhoeck \& Ruprecht, 2018), p. 118.
}

(c) Cambridge University Press 2019 
from its inception, the American moral governmental theory of the atonement gave new meaning to old theological terms. Edwardseans like John Smalley affirmed the idea of imputation, but insisted that Christ's righteousness is not 'so imputed to them as to become, to all intents and purposes, their own righteousness'. ${ }^{3}$ Jonathan Maxcy and others upheld the doctrine of substitution, but believed that the 'atonement is a substitute for punishments' and not for actual people. ${ }^{4}$ For this reason, Daniel W. Cooley and Douglas A. Sweeney have recently critiqued Oliver Crisp's assertion that the American moral governmental theory is a 'penal non-substitution'. ${ }^{5}$ Instead, they have labelled the Edwardsean view of the atonement a 'non-distributive form of penal substitution'. ${ }^{6}$ Such theological hair-splitting stems from the fact that Edwardseans did not recognise an ontological unity between the atonement and the act of salvation. In fact, one of the primary differences between Jonathan Edwards and his successors on the doctrine of the atonement was that the latter denied any real connection between these two events. This separation drove them to redefine a number of doctrines, including the atonement itself.

Because the Edwardsean atonement is not a literal payment of a debt or a transfer of righteousness, New England theologians were not interested in the worth or value of Christ's death. In fact, in their view the atonement itself had no intrinsic value in any measurable sense. Its ultimate purpose was to uphold the honour of God's justice in such a way that God's subsequent pardon of sinners could be completely free. Therefore, they conceived of Christ's atonement not as the actual punishment under the law, but as an act of public suffering equivalent to the damnation of sinners in hell, whereby God manifested his displeasure with sin, vindicated his moral governance and made sovereign grace possible. As Samuel Hopkins explains, Christ 'suffers the evil which the law threatens for sin, or a complete equivalent, so as fully to answer the end of the threatening of the law, and all the purposes of moral government, consistent with the pardon of the sinner, as much as if the curse had been executed on the transgressor'? Due to the hard distinction between atonement and pardon, the American moral governmental theory of the atonement hinged on the idea of equivalence. ${ }^{8}$

\footnotetext{
${ }^{3}$ John Smalley, 'Justification through Christ, An Act of Free Grace', in Edwards Amasa Park (ed.), The Atonement, Discourses and Treatises by Edwards, Smalley, Maxcy, Emmons, Griffin, Burge, and Weeks (Boston: Congregational Board of Publication, 1859), p. 55.

${ }^{4}$ Jonathan Maxcy, 'A Discourse, Designed to Explain the Doctrine of Atonement. In Two Parts, Part II', in Romeo Elton (ed.), The Literary Remains of Rev. Jonathan Maxcy, D.D. (New Haven: [n.p.], 1844), p. 70.

${ }^{5}$ Oliver D. Crisp, 'Penal Non-Substitution', Journal of Theological Studies 59/1 (2008), pp. 140-68.

${ }^{6}$ Cooley and Sweeney, 'The Edwardseans', p. 122. Cooley and Sweeney explain, 'Instead of Christ being the substitute victim for man, Christ's sufferings are substituted for man's punishment. Instead of the atonement being distributed to each one of God's elect individually, it is construed as a collective satisfaction for all who believe.'

${ }^{7}$ Samuel Hopkins, cited in Edwards Amasa Park, 'Introductory Essay', in The Atonement, Discourses and Treatises, p. lii.

${ }^{8}$ Oliver Crisp explains, 'It is penal in nature, because it demonstrates what the consequences attending sin are, being a suitably equivalent punishment to what would be meted out to sinners in hell.' Crisp later adds, 'Although there is a sense in which he stands "in our room and stead", he does so by virtue of offering a suitably equivalent act of atonement and demonstrates the heinousness of sin by his becoming an example of what would happen to human sinners if they were punished for their sins. Because Christ does this, God is able to forgive sinners. His moral governance is vindicated, and Christ's work generates a merit sufficient in principle for the salvation of all humanity.' Oliver D. Crisp, 'The Moral Government of God: Jonathan Edwards and Joseph Bellamy on the Atonement', in After Jonathan Edwards, p. 87.
} 
However, if Edwardseans denied the commercial and pecuniary nature of the atonement, insisting instead upon the satisfaction of divine justice, in what way did they understand Christ's sufferings to be 'equivalent' to the punishment meted out upon sinners in hell? If there is no quid pro quo exchange in the atonement, what exactly is equivalent? This article will demonstrate that the Edwardsean idea of equivalence is best understood in terms of a countervailing, or the achieving of a moral equilibrium. ${ }^{9}$ According to Edwards' disciples, Christ's atonement was not quantifiably equivalent to the penalty of the law, but morally and meaningfully equivalent. In other words, Christ's physical and psychological sufferings were not equal in amount or degree to a sinner's damnation. Rather, Christ's substitution for divine punishment - not for sinners - exhibited sufficient divine displeasure against sin to effectively communicate his character and to offset the evil effects of sin. In the American moral governmental scheme, Christ's was not a commutative atonement, but a countervailing atonement.

\section{A non-saving atonement}

In his anthology of Edwardsean works on the atonement, Edwards Amasa Park suggests that 'the most distinguishing feature of the "new divinity" is, that it gives a prominence to God as a Sovereign in applying and conducting, as well as originating the redemptive work' ${ }^{10}$ The idea of divine sovereignty is the abiding principle which informs every aspect of the American moral governmental theory of the atonement. The division between atonement and pardon in the Edwardsean scheme is designed to safeguard divine sovereignty by preventing any notion that God 'owed' salvation to a sinner possessing Christ's merit. Nathanael Emmons clearly stated that Christ's 'death could not merit our deliverance from future punishment, nor his obedience merit eternal life for us'. ${ }^{11}$ For this reason, both commutative and distributive justice were typically rejected because they implied that a believer could take their paid sum or their personal righteousness before God at judgment and demand to be saved. According to Jonathan Edwards Jr., none

will pretend that commutative justice is satisfied by Christ; for the controversy between God and the sinner is not concerning property. Nor is distributive justice satisfied. If it were, there would be no more grace in the discharge of the sinner, than there is in the discharge of a criminal, when he hath endured the full punishment to which, according to law, he hath been condemned. ${ }^{12}$

At all costs, the Edwardseans were defending the absolute freedom of God to save sinners. The idea of public justice fit nicely into their theological system because it encompassed both justice and goodness, law and benevolence. ${ }^{13}$

\footnotetext{
'In this article 'countervail' will simply mean to offset the effect of something by countering it with something of equal force, weight or meaning.

${ }^{10}$ Edwards Amasa Park, 'Introductory Essay', p. xii.

${ }^{11}$ Nathanael Emmons, 'The Purchase of Christ's Blood', in The Atonement, Discourses and Treatises, p. 129.

${ }^{12}$ Jonathan Edwards Jr., 'Inferences and Reflections', ibid., p. 37.

${ }^{13}$ Jonathan Edwards Jr. taught that general or public justice 'comprehends all moral goodness'. He goes on, 'To practice justice in this sense, is to practice agreeably to the dictates of general benevolence, or to seek the glory of God and the good of the universe.' Jonathan Edwards Jr., 'Grace Consistent with Atonement', ibid., p. 21.
} 
Consequently, the American moral governmental atonement was not a saving atonement. Indeed, it was one of the first theories of the atonement in the Calvinist tradition that lodged no salvific power in the atonement itself. Unlike many general atonement models, the Edwardsean atonement was never 'applied' or gifted to sinners. Faith was not an act of union whereby one possessed the work of Christ by virtue of being one with him. Samuel Hopkins went so far as to declare that the Sovereign Moral Governor was under no obligation to regenerate the sinner once he had atoned for his $\sin .{ }^{14}$ If the sufferings of Christ could be distributed, transferred or monetised in any way, the grace of God would be eviscerated. This doctrine of atonement crossed denominational lines. Jonathan Maxcy's Southern Baptist disciple, William B. Johnson, asserted,

In itself considered, the atonement of Christ does not deliver any soul from condemnation. It is the interest which the soul has in the benefits of the atonement that effects this deliverance; an interest that depends not upon the principle of atonement, but upon that by which it has been provided, and in which it originates, viz.: Love, or infinite benevolence, under the influence of which, this interest will be imparted according to the righteous and sovereign will of God. For he will have mercy, on whom he will have mercy, and he will have compassion on whom he will have compassion. ${ }^{15}$

The fundamental separation between the atonement and salvation guaranteed that grace was sovereign and that faith itself was the efficient cause of salvation - not Christ's work on the cross. The American moral governmental atonement is a nonsaving atonement. In this model, before the rebirth, nothing is ever really the property of the believer other than to be pardoned of their crimes. Therefore, because nothing is given, Christ's sufferings should not be measured on a graduated scale.

As a result, unlike Jonathan Edwards, his disciples were hesitant to depict the sufferings of Christ in terms of a commercial amount. ${ }^{16}$ They insisted that the biblical language of 'purchase' and 'redeem' were simply metaphorical and not to be taken literally. Their reasons for doing so were several. By utilising the Calvinist notion of imputation and emphasising the atonement as a payment of a debt, Universalists like John Murray gave the New Divinity fresh motivation to distance themselves from traditional Calvinism. ${ }^{17}$ Republican ideals of public leadership during the Revolutionary period underscored the moral fabric of honour, something which the New Divinity adopted into their own views of God and salvation at the expense of monetary themes. ${ }^{18}$ The Edwardseans also exhibited such a strong aversion to the avarice and

\footnotetext{
${ }^{14}$ Samuel Hopkins, cited in Edwards Amasa Park, 'Introductory Essay', p. lxi.

${ }^{15}$ William B. Johnson, 'Love Characteristic of the Deity', in Thomas J. Nettles (ed.), Southern Baptist Sermons on Sovereignty and Responsibility (Harrisonburg, VA: Sprinkle Publications, 2003), p. 60.

${ }^{16}$ According to Brandon James Crawford, 'Edwards did not question the equivalence of Christ's sufferings in any real sense, but only in a psychological sense. In other words, he questioned the premise that Christ's mental and emotional state could have been identical with the damned in hell during his passion, because he was the God-man; and in experience, he was absolutely holy.' Brandon James Crawford, Jonathan Edwards on the Atonement: Understanding the Legacy of America's Greatest Theologian (Eugene, OR: Wipf \& Stock, 2017), p. 117.

${ }^{17}$ For a thorough treatment of Jonathan Edwards, Jr. and his analysis of universalism, see Ferm, Jonathan Edwards the Younger, pp. 106-13.

${ }^{18}$ Mark Noll, America's God: From Jonathan Edwards to Abraham Lincoln (New York: OUP, 2002), pp. 290-91.
} 
greed of the emerging market economy that, in some ways, it imbued their de-commercialised doctrine of atonement. In The Market Revolution: Jacksonian America 1815-1846, Charles Sellers identifies this aversion as part of the New Divinity's anticapitalist polemic'. ${ }^{19}$ On the other hand, Mark Valeri insists that, for the Edwardsean generation, 'the promise of social solidarity lay with a free market'. ${ }^{20}$ Nevertheless, because moral governmentalists did not affirm the inherent worth of the atonement, and because they believed their generation to be unduly influenced by personal wealth, they were less prone to quibble over the commerce of Christ's work. Such was not the intent of the atonement. Furthermore, the Edwardsean atonement was not simply de-commercialised; it was also de-quantified. In their view, Christ's sufferings should not be placed on a spectrum. According to D. P. Rudisill, this non-graduated aspect of the Edwardsean atonement began almost immediately after Jonathan Edwards:

It should be observed that Bellamy does not say a great deal about the nature and intensity of Christ's suffering. He does not leave the reader in doubt, however, as to his view that Christ's suffering was great and that it came upon Him in the exercise of His mediatorial office. In fact, by holding that Christ satisfied general justice, it suffices to maintain that His suffering was unfeigned and that it was attendant to His dying. It is not necessary to hold that He endured a specified quantum of suffering. The point to be understood here is that Bellamy stresses the public display of God's vindictive justice in the death of His Son rather than the precise nature and intensity of Christ's suffering. At this important point Bellamy differs from Edwards who laid special stress upon the sufferings of Christ. $^{21}$

From the beginning of the New Divinity movement, it seems, Christ's sufferings were not enumerated or counted. New England theologians like Jonathan Edwards, Jr. insisted that 'it is not true that Christ endured an equal quantity of misery to that which would have been endured by all his people had they suffered the curse of the law'. ${ }^{22}$ By virtue of the fact that Jesus was both fully man and fully God, his suffering was, in some sense, categorically different. To suggest that Christ bled a set number of ounces of blood or endured a predetermined degree of pain was utterly ridiculous in the minds of the New Divinity. In their view, a strict equality between the suffering of sinners in hell and that which the God-man endured upon the cross is nonsensical in light of the hypostatic union. Therefore, in one sense, Edwardseans were not concerned with the moral quantity of the atonement, but its moral quality. At stake was the rectitude of the Moral Governor. This is precisely why they chose to employ the word 'equivalent' in their description of Christ's work, and their understanding of this word shaped their entire view of the atonement.

\footnotetext{
${ }^{19}$ Charles Sellers, The Market Revolution: Jacksonian America 1815-1846 (Oxford: OUP, 1991), p. 206.

${ }^{20}$ Mark Valeri, 'Jonathan Edwards, the Edwardsians, and the Sacred Cause of Free Trade', in David W. Kling and Douglas A. Sweeney (eds), Jonathan Edwards at Home and Abroad: Historical Memories, Cultural Movements, Global Horizons (Columbia: University of South Carolina Press, 2003), p. 96.

${ }^{21}$ Rudisill, The Doctrine of the Atonement, p. 41.

${ }^{22}$ Jonathan Edwards Jr., 'Inferences and Reflections', p. 34.
} 


\section{A moral and meaningful equivalence}

If Christ did not pay anything to the sinful debtor's personal account, and if he did not exchange his own righteousness to be theirs, then what has the atonement to do with salvation? How does Christ's work traverse this soteriological divide? The concept of equivalence is how the Edwardseans established the legal bridge between condemnation and clemency. The moral governmental atonement is a vicarious substitution, but not in a personal sense. Nothing is paid or transferred. Instead, the evil effects of sin must be countervailed, not commuted. Christ's death must be displayed and not distributed. Therefore, in bringing balance to the moral universe, the atonement of Christ is the moral and meaningful equivalent, not the quantifiable equivalent, of what sinners would rightfully endure in hell. What is most important about the atonement is the message it sends about the honour of God and the integrity of his law. As Joseph Bellamy explains, in Christ's suffering, God 'abates nothing, but appears as great an enemy to sin, in his conduct, as if he had damned the whole world. His Son also owns the sentence just; he takes the cup and drinks it off. Considering the infinite dignity of his person, his sufferings were equivalent to the eternal damnation of such worms as we. ${ }^{23}$

Ironically, in the American moral governmental theory of the atonement, the Edwardseans co-opted one of Jonathan Edwards' most fundamental principles God's glory displayed - in order to distance themselves from their progenitor. Instead of insisting upon the degree or amount of Christ's sufferings as Edwards often did, his disciples believed that the exhibition of God's glorious attributes (i.e. justice, goodness) is the proper equivalent to hellish suffering which ultimately vindicates God's moral governance. Christ's work is a virtuous statement. Its equivalence is not measured in amount or worth, but in its revelation of the divine ethic. As Stephen West notes, 'The same character, the same disposition of the Deity, which would have appeared in the death of the sinner, was designed to be exhibited in the death of Christ. ${ }^{24}$ Christ's atonement is not a monetary equivalence, but a moral and meaningful equivalence, designed to publicly honour God's justice and to communicate his will for the moral universe.

As a result of this countervailing principle, the Edwardseans were largely incapable of discussing the atonement without some mention of equivalence or a similar idea. In some ways, they based their entire project on it. Jonathan Edwards, Jr. believed that the 'principal reason' why so many opposed the moral governmental view is because 'they have conceived that the idea of Christ's having suffered an equivalent to the punishment to which all his people were exposed, is inconsistent with grace in their pardon' ${ }^{25}$ In other words, for the Edwardseans, one could not properly affirm the American moral governmental theory of the atonement unless one first understood the meaning of equivalence. It helped Edward Dorr Griffin rebut the notion that Christ's death could be measured in units of pain. Griffin was aware that many were attempting to count the sufferings of Christ as a sort of divine currency, but he insisted that the worth of the atonement was not in terms of similar misery, but in its supreme expression of love and lawfulness:

\footnotetext{
${ }^{23}$ Joseph Bellamy, The Works of the Rev. Joseph Bellamy, D.D., vol. 1 (New York: Stephen Dodge, 1811), p. 438.

${ }^{24}$ Stephen West, 'West's Essay', pp. 33, 35, 37, 63; cited in Edwards Amasa Park, 'Introductory Essay', p. lxix.

${ }^{25}$ Jonathan Edwards Jr., 'Inferences and Reflections', p. 36.
} 
This was enough, and the endurance of the same misery in measure and kind was by no means necessary. If to the purpose of supporting the divine law, the sufferings of Christ, considering his infinite interest in the Father's love, were equivalent to the eternal misery of those for whom he died, it was sufficient: and if to such a purpose they were equivalent to the eternal misery of all Adam's race, they were sufficient, if expressly endured for so many, to make atonement 'for the sins of the whole world'. ${ }^{26}$

Because the atonement is a showcase of God's moral probity, literalism has no place in the American moral governmental model. Christ's death is neither a literal payment nor a literal punishment under the law. In regard to the latter, Edwardseans were convinced that Christ did not actually endure the law's penalty. God the Father did not execute the same lawful judgment due sinners upon his own Son. Therefore, Christ's sufferings were not precisely what sinners experience in hell. Rather, there is an equivalence. In terms of what occurs to sinners under divine wrath, Christ's death is not directly comparable. However, in terms of what it says about God, Christ suffered something equal to the law's retribution. Samuel Hopkins insisted that Christ 'suffered the evil with which sin is threatened in the law, or the penalty and curse of the law, or that which is equivalent'. ${ }^{27}$ Put another way, the effects of sin are publicly displayed in the crucified Christ so that the entire moral universe might consider God's rectitude and sin's heinousness. The atonement is a moral persuasion that God is to be honoured and sin is to be hated. Joseph Bellamy avers, 'The sufferings of Christ, all things considered, have as much displayed God's hatred to sin, and as much secured the honor of his law, as if the whole world had been damned. ${ }^{28}$ This is the essence of rectoral justice, and at the heart of the matter is equivalence.

When the Edwardseans were not referring to equivalence explicitly, they were using other words and phrases in order to better elucidate the idea that the moral messaging of the atonement was paramount for interpreting the level of anguish Jesus endured. According to Stephen West, God's 'displeasure against sin is made to appear, to equal advantage, as it doth in the execution of the penalties of the law; in whatever way it be done'. ${ }^{29}$ Edwards Amasa Park explains West's theology: 'The atonement is not made, then, by executing the literal penalty of the law, but in some other way, equally advantageous to the honor of the law, and satisfactory to its main spirit and aim. ${ }^{30}$ For the Edwardseans, the nature and extent of the atonement were predicated upon its intent. Since God ultimately desires to display himself to his creation, the atonement's primary 'aim' was to serve as a glorious platform to the moral consistency of God. It reveals who and how God is in a way that prices and purchases cannot. In other words, the American moral governmental theory of the atonement is an ethical exhibition. For this reason, Oliver Crisp's labelling of Bellamy's view as a 'penal example' is much more apt than a 'penal non-substitution'. ${ }^{31}$ Edwardseans adopted a lawful, not a literalist, hermeneutic of the atonement. As long as the honour of the law is upheld, and

\footnotetext{
${ }^{26}$ Edwards Dorr Griffin, 'Nature of the Atonement', in The Atonement, Discourses and Treatises, p. 238.

${ }^{27}$ Samuel Hopkins, cited in Edwards Amasa Park, 'Introductory Essay', p. li.

${ }^{28}$ Bellamy, Works, vol. 1, p. 292.

${ }^{29}$ Stephen West, 'West's Essay', p. 28; cited in Edwards Amasa Park, 'Introductory Essay', p. lxxv.

${ }^{30}$ Edwards Amasa Park, 'Introductory Essay', p. lxxv.

${ }^{31}$ Crisp, 'The Moral Government of God, p. 86.
} 
merits and penalties are non-transferrable, satisfaction of divine justice is necessary, but its manner can in theory be negotiated. For Edwards Dorr Griffin, non-literal equivalence was best described in terms of room:

Christ, therefore, could not sustain our legal punishment, or the literal penalty of the law ... The plain truth is, that the sufferings of Christ were not our punishment, but only came in its room. They were not the death of the identical 'it', that had sinned. They answered, indeed, the same purpose as related to the honor of the law, but they were not the same thing, and could not be the same thing, without an absolute personal identity. So far from enduring our punishment, the plain fact is, he died to prevent our punishment. ${ }^{32}$

The Edwardseans staked their entire doctrine of atonement on the idea of equivalence, whether explicitly or implicitly. In fact, they were even willing to entertain commercial and pecuniary language if it supported the honour of the law. According to Jonathan Maxcy, 'The sufferings of Christ appear to have been available to the procurement of salvation, so far as they portrayed God's displeasure against sin, and evinced the infinite value he set upon his own character and law. ${ }^{, 33}$ The 'value' of Christ's work is the revealed character of God. In this sense, it is an infinite worth. Therefore, the atonement is a moral and meaningful equivalence to the hellish judgment of sinners.

\section{A countervailing atonement}

However, why was such a moral response imperative? Why did the Edwardseans relentlessly insist that the atonement was absolutely necessary? The idea of equivalence was sine qua non with the American moral governmental theory of the atonement because of the way that Edwardseans understood the nature of divine justice and the moral universe. New Divinity men had a very high view of God; however, they also had an extremely high view of sin. As a result, they believed that the moral universe is a fixed universe, but also a fragile one. As demonstrated in Adam, even the seemingly smallest sin disrupts all of God's good creation. ${ }^{34}$ It defies the authority of God and it permeates the entire world with its evil. Therefore, because sin is always dishonourable to God, and because the Moral Governor must always be seen as supremely just and good, his moral universe rests on a delicate moral balance. Sin doesn't simply elicit a response from the Moral Governor; it demands to be countervailed with something that publicly restores the integrity of the law and the honour of its Ruler. Evil must be counterweighted with good, injustice with justice, in order that God's glorious attributes might be displayed all the more. The nefarious effects of sin must be offset by the shining character of God and shown to be infinitely wicked. God must indeed accomplish both. Thus, Christ's atonement was not concerned with paid sums or commercial amounts, but with upholding the moral fibre of God's honour in the same degree that it had been assaulted by $\sin$.

\footnotetext{
${ }^{32}$ Edward Dorr Griffin, 'Nature of the Atonement', p. 235.

${ }^{33}$ Jonathan Maxcy, 'A Discourse, Designed to Explain the Doctrine of Atonement', in The Atonement, Discourses and Treatises, p. 89.

${ }^{34}$ In his System of Doctrines, Samuel Hopkins contends that 'one reason why it was so ordered that one, the first act of sin, should spread total corruption and ruin over all the countless myriads of the human race, was to discover to all intelligent creatures the evil nature and tendency of sin.' Samuel Hopkins, 'System of Doctrines', in The Works of Samuel Hopkins, vol. 1 (Boston: Doctrinal Tract and Book Society, 1854), pp. $242-3$.
} 
Put simply, equivalence is the idea which supports the Edwardsean view that the wickedness of sin carries as much moral meaning as the integrity of God. Sin is as evil as divine justice is good. Therefore, what Christ suffered on the cross must adequately display the evil of sin as much as it displays the goodness of his law. By providing a moral and meaningful equivalent to the punishment meted out in hell, Christ's countervailing atonement performs one as much as the other by ascribing equal moral weight to both. As much as God is dishonoured by sin, Christ's atonement declares God's hatred for it. And as much as God's moral government is shown to be despicable by sin, Christ's work vindicates it. There is a kind of symmetry in God's universe.

The moral and meaningful equivalence between the damnation of sinners and the sufferings of Christ is a countervailing because the universe must always retain this moral order. God is only as just as his moral universe is secure. Therefore, the Edwardseans conceived of the atonement as a proportional event. According to Jonathan Maxcy, 'The system of redemption rises into view like a magnificent edifice, displaying the greatest order, proportion, and beauty. ${ }^{35}$ Since God's moral universe will always achieve an equilibrium of sorts, Christ's work is a stabilising effort to highlight the justice of God by equally highlighting the heinousness of sin. Hopkinsian theodicy is built upon the idea that evil exists in order to be countervailed, and in some sense outshined, by an equally moral and meaningful act of goodness. As a result, Edwardseans often depicted the atonement in terms of its order, and sin in terms of its disorder. John Smalley praised the 'gospel constitution' for its 'fitness of things' and described sin as an 'anarchy' which impugns the 'divine administration'. ${ }^{36}$ So strong was this Edwardsean sense of public morality that Edward Dorr Griffin believed that Christ's atonement was an attempt to 'convince the universe' that God should punish sin and to 'make an impression on the universe' that he will always support his law. ${ }^{37}$ In this respect, the language of the American moral governmental theory of the atonement could sound similar to that of moral influence theory. ${ }^{38}$

In his sermon titled 'The Necessity of the Atonement', Nathanael Emmons represents the New Divinity countervailing position well when he says,

God is love. Before the foundation of the world, there was no ground for considering love as divided into various and distinct attributes. But after the creation, new relations arose; and in consequence of new relations, more obligations were formed, both on the side of the Creator and on that of his creatures. Before created beings existed, God's love was exercised wholly towards himself. But after moral beings were brought into existence, it was right in the nature of things that he should exercise right affections towards them, according to their moral characters. That is, so long as God remains the Creator, and men remain his creatures, he is morally obliged to exercise these different and distinct feelings towards them. He must be disposed to do good to the innocent, to punish the guilty, and at the same time to forgive them. ${ }^{39}$

\footnotetext{
${ }^{35}$ Jonathan Maxcy, 'A Discourse, Designed to Explain the Doctrine of Atonement', p. 107.

${ }^{36}$ John Smalley, 'None But Believers Saved, Through the All-Sufficient Satisfaction of Christ,' in The Atonement, Discourses and Treatises, pp. 76, 78.

${ }^{37}$ Edward Dorr Griffin, 'Nature of the Atonement', pp. 155, 193.

${ }^{38}$ Moral influence theory, as associated with the work of Peter Abelard (1079-1142), holds that the main purpose and result of Christ's death was to influence or persuade mankind toward moral improvement.

${ }^{39}$ Nathanael Emmons, 'Necessity of the Atonement', in The Atonement, Discourses and Treatises, p. 116.
} 
God is 'obliged' to 'exercise right affections' towards sin. In the American moral governmental view, God is not obligated to punish sin by the law; he is instead lawfully obligated to punish sin. In other words, it is not imperative that sinners be damned by the law itself (as they are in hell), but only that the law itself be honoured (as it is in Christ's death). Therefore, Edwardseans believed that the honour of the law could be maintained without its actual execution, and this is precisely what happened at Calvary when Jesus died not by receiving the actual penalty of the law, but its equivalent.

Christ countervailed the evil effects of sin with an act of suffering equivalent to the punishment meted out upon sinners in hell, all for the honour of the law, which had been equally dishonoured by sin. In the minds of the Edwardseans, the 'value' of the atonement need not be transferred, exchanged or merited personally to sinners' accounts. Its worth should not be measured monetarily but in terms of the value of the law, something they felt was immeasurable. Therefore, the atonement itself did not save so much as it vindicated the moral governance of God by revealing sin to be as evil as God's law is just. The idea of equivalence upon which they staked their entire doctrine of atonement was not grounded in the exaction of the law, but in its honour. The American moral governmental theory of the atonement did not frame Christ's death in terms of its moral quantity, but in the moral quality it took to countervail the immoral effects of sin.

In some sense, the Edwardsean view was a soteriological response to three economic, political and theological factors: market, monarchy and Murrayites. As a result, by insisting upon the moral and meaningful equivalence of Christ's work as opposed to its monetary value, the American moral governmental theory of the atonement was a highly contextualised doctrine which nevertheless remained within the bounds of Reformed atonement theology due to its relentless, albeit novel, commitment to divine sovereignty. Drawing from the thought of their progenitor as well as from their own age, the Edwardseans demonstrated the elasticity of atonement theology and the endurance of Edwards' ideas into subsequent generations.

Cite this article: Todd OT (2019). A countervailing atonement: The meaning of equivalence in the American moral governmental theory of the atonement. Scottish Journal of Theology 72, 375-384. https://doi.org/10.1017/S0036930619000590 